\title{
26. GAS HYDRATES IN SEDIMENTS OF HOLES 497 AND 498A, DEEP SEA DRILLING PROJECT LEG $67^{1}$
}

\author{
William E. Harrison and Joseph A. Curiale, ${ }^{2}$ Oklahoma Geological Survey, \\ University of Oklahoma, Norman, Oklahoma
}

\section{INTRODUCTION}

Gas hydrates are icelike materials that form when specific conditions of temperature, pressure, and gas composition are simultaneously satisfied. Among the first descriptions of gas hydrates under natural conditions was that of Hammerschmidt (1940), who found them in pipelines used to transport natural gas. Milton (1976) indicates that conditions are suitable for the presence of gas hydrates in areas affected by permafrost and cites studies suggesting that large quantities of gas exist in hydrate form.

Ordinary ice crystallizes in the hexagonal system, and the voids that result from such crystal geometry are capable of accommodating only hydrogen and helium. Gas hydrates, however, crystallize in the cubic system and occur in Structure I (unit cell $=12 \AA$ ) or Structure II (unit cell = $17 \AA$ ) (Hitchon, 1974). These structures have cavities or voids large enough to accommodate small gaseous molecules. Methane, ethane, propane, and carbon dioxide are among the gases commonly found in sediments that can exist in gas hydrate form. Gas molecules with dimensions equal to or larger than $n$-butane are too large to fit into the voids, whereas very small gas molecules such as helium, neon, and hydrogen are probably too small to form hydrates (Parrish and Prausnitz, 1972). The forces that exist between the gas molecules and the crystalline solid are of the Van der Waals type, thus gas hydrates are not true chemical compounds. The relation is essentially a physical one resulting from cagelike openings that exist in the lattice of icelike solids and the free gas molecules that occupy such openings (Ionescu, 1978).

Kvenvolden and McMenamin (1980) have compiled information on several areas of the world's ocean where gas hydrates are thought to exist in seafloor sediment. Most such areas were defined on the basis of a BSR (bottom-simulating reflector) in seismic records. Leg 67 involves an area where BSRs are not readily discernible, but cores recovered at two sites provided abundant evidence for the presence of gas hydrates.

Gas hydrates recovered during Leg 67 were invariably associated with stratigraphic sequences containing high-porosity sediments. Material recovered from a core catcher at Hole 497 (Core 39) was an icelike substance

\footnotetext{
${ }^{1}$ Aubouin, J., von Huene, R., et al, Init. Repts. DSDP, 67: Washington (U.S. Govt. Printing Office).

2 Present address: Science and Technology Division, Union Oil Company of California, Brea, California.
}

that contained no sediment at all. The particle was approximately $2 \mathrm{~cm}$ in length and attests to porosity conditions which, if encountered in lithified sediment, would be described as vuggy. At Hole 498A (Core 15), icelike material cemented relatively coarse vitric sands to the extent that the core sediment was well-indurated and competent. A piece of this material was set aside in the core lab; it collapsed into a pile of loose sand particles after coming to ambient temperature and pressure. The porosity of this material was estimated to be $20 \%$. The material recovered from Holes 497 and 498A occurred in sediments that have high porosity, which suggests the possibility of some type of lithologic control on the presence of gas hydrates.

The association between unconsolidated and very porous sands and gas hydrates has been noted in shallow wells drilled by the petroleum industry in the Northwest Territories, Canada (Bily and Dick, 1974). Yefremova and Zhizhchenko (1974) described an icelike material, recovered from Black Sea cores, which melted quickly under surface conditions. This material occurred in large cavities and was recovered from a subbottom depth of 6.5 meters in a water depth of 2000 meters. Makogon et al. (1971) described the gas hydrates that exist in Messoyakha Field in the northeastern part of western Siberia. Porosities of the sands that contain the hydrates range from $16 \%$ to $38 \%$ (averaging $25 \%$ ). Thus there is a recurrent association between gas hydrates and high-porosity rock sequences.

Figure 1 shows the stability field for hydrates of varying gas composition. The stable pressure-temperature $(P-T)$ regime for hydrates in excess water is affected by conditions of ionic strength (i.e., $\mathrm{NaCl}$ in water) and by concentrations of gaseous components. The simplest hydrocarbon, methane, forms a hydrate under $P-T$ conditions that exist in many regions in the world's deep $(>500 \mathrm{~m})$ oceans. The approximate $P-T$ conditions for Core 39 of Hole 497 and for Hole 498A are well within the stability field for the most commonly occurring hydrates. Table 1 shows the observations and measurements made on gas hydrate-bearing sediments recovered from Holes 497 and 498A.

Hole 497. Gas expansion cracks were noted in Core 18, and the approximate pressure of the gas in the cracks was determined by puncturing the core liner with a needle fitted with a gauge. The pressure indicated by this method varied from 3 to $17 \mathrm{psi}$ (Table 1). Cores 29, 30 , and 36 to 39 had pressures great enough to eject sediment from the plastic liners onto the deck. A gas 


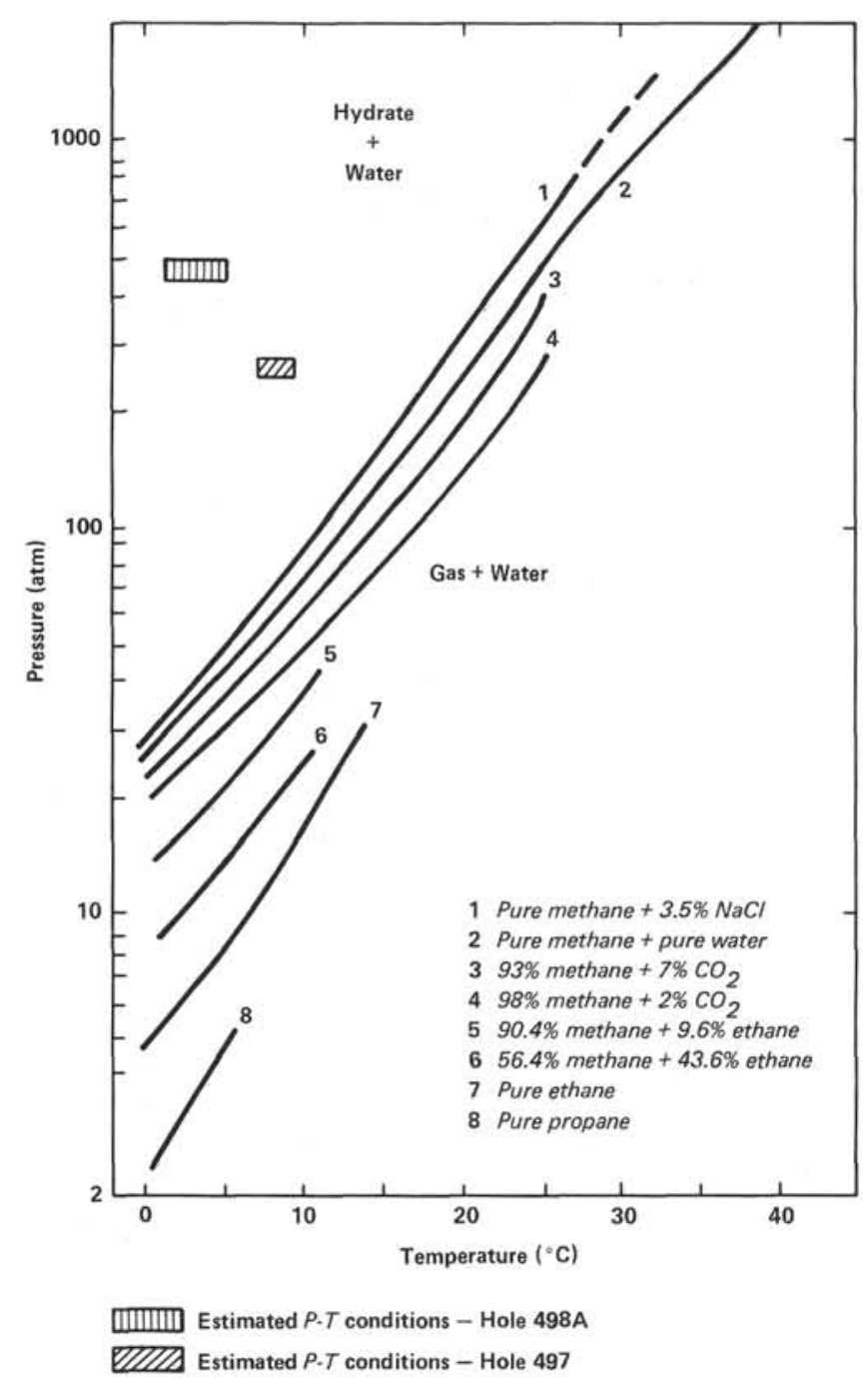

Figure 1. Pressure-temperature $(P-T)$ stability field for hydrates of varying gas composition. (Note the effect of $3.5 \% \mathrm{NaCl}$ on the stability field of a pure methane hydrate [after Tucholke et al., 1977]).

sample taken through the plastic liner (Core 36, Section $5,104 \mathrm{~cm}$ ) contained $84 \%$ methane and had an ethane level of $169 \mathrm{ppm}$ (volume/volume; v/v). The latter value was approximately two times that noted in most of the shallower cores. A solid piece of hydrate about $2 \mathrm{~cm}$ in size was recovered from the core catcher of Core 39. The gas liberated when this material melted generated $18.4 \mathrm{psi}$ in a sealed vessel with a volume of $232 \mathrm{~cm}^{3}$; methane content was about $90 \%$ and the ethane level was $501 \mathrm{ppm}(\mathrm{v} / \mathrm{v})$. A gas sample (Core 39, Section 5, 37 $\mathrm{cm}$ ) taken through the liner contained $80 \%$ methane and $194 \mathrm{ppm}(\mathrm{v} / \mathrm{v})$ ethane. Thus shipboard data show a marked increase in ethane concentrations for gases liberated from hydrates.

Hole $498 \mathrm{~A}$. Cores 6 and 8 were ejected from the plastic liner by expanding gas. A gas sample taken through the liner in Core 6 had a methane level of $83 \%$ and an ethane concentration of $152 \mathrm{ppm}(\mathrm{v} / \mathrm{v})$. The highest ethane content for shallower cores was about $60 \mathrm{ppm}$ (v/v). Core 8 had $83 \%$ methane and $347 \mathrm{ppm}(\mathrm{v} / \mathrm{v})$ ethane. Core 15 comprised the ice-cemented vitric sands described earlier and contained gas that had $83 \%$ methane and nearly $2000 \mathrm{ppm}(\mathrm{v} / \mathrm{v})$ ethane.

\section{METHANE SOLUBILITY IN WATER}

When high concentrations of methane are detected in DSDP cores, it is helpful to know if the gas (1) may be exsolved from pore water, (2) exists as a free phase, or (3) is liberated from hydrates. Figure 2 shows the solubility of methane in pure water as determined by Culberson and McKetta (1951). Shipboard experiments involving recovered hydrates and pressure bombs fitted with gauges indicate that the sediment recovered from Hole 497 contained 4.08 mole percent methane (relative to interstitial water), whereas Hole 498A sediment yielded 6.10 mole percent methane. Such concentrations are clearly in excess of those that may be expected from exsolved methane. Figure 2 is the solubility field with estimated $P-T$ conditions for Holes 497 and $498 \mathrm{~A}$ and indicates the stability field for a pure methane-pure water hydrate. This nomogram may be useful in determining whether methane concentration levels are high enough to suggest the presence of hydrates. Figure 3 shows a sample of the hydrate-cemented vitric sand recovered at Hole 498A.

\section{POSSIBLE RELATION BETWEEN HYDRATES AND HIGH-POROSITY LITHOLOGIES}

Hitchon (1974) summarized the dimensions and packing arrangements of gas hydrates, and it appears that both sandstones and shales have pore openings large enough to accommodate both Structures I and II. Heling (1970) suggests that lithified shales with $20 \%$ porosity will have pore radii on the order of $100 \AA$. Clay-rich materials recovered in DSDP operations are often poorly lithified, therefore the 100 - $\AA$ pore radii may represent a minimum size constraint for gas hydrates to exist in muds and shales. Certain clay minerals have charge deficiencies and adsorb molecules or compounds with specific size-charge characteristics. Thus there may exist a form of chemical competition for gases in clay-rich sediments. Such a mechanism may serve to influence the extent to which hydrates can exist in such lithologies. There appear to be no unequivocal criteria that would prevent hydrates from forming in shales or other clayrich rocks.

There are, however, some factors that may result in the preferential formation of hydrates in high-porosity lithologies. Empirical observations on the association between high-porosity rocks and hydrates were mentioned earlier. Hydrates are formed when specific $P-T$ and gas composition conditions are satisfied. One of the factors that affects the concentration of gaseous molecules in a lithologic unit is rate of movement under specific porosity and permeability conditions. The most likely mechanism for movement of such molecules is diffusion. If diffusion occurs in an isotropic medium and initiates at a point source, the diffused area will be spherical and radii will be greater per unit of time. Sedi- 
Table 1. Compilation of data and observations: Holes 497 and 498A, Leg 67.

\begin{tabular}{|c|c|c|c|c|c|c|c|}
\hline Hole & Core & $\begin{array}{l}\text { Sub-bottom } \\
\text { Depth } \\
\text { (m) }\end{array}$ & Observation/Comment & $\begin{array}{c}\mathrm{CO}_{2} \\
(\%)\end{array}$ & $\begin{array}{c}C_{1} \\
(\%)\end{array}$ & $\begin{array}{c}\mathrm{C}_{2} \\
(\mathrm{ppm}) \\
(\mathrm{v} / \mathrm{v})\end{array}$ & $\begin{array}{c}C_{3} \\
(\mathrm{ppm}) \\
(\mathrm{v} / \mathrm{v})\end{array}$ \\
\hline \multirow[t]{12}{*}{497} & 18 & $159.0-168.5$ & Expansion cracks (gas pockets) separating core in liner (13 psi) ${ }^{\mathrm{a}}$ & 1.1 & 87.4 & 99.0 & 1.0 \\
\hline & 19,20 & $168.5-187.5$ & Expansion cracks & $2.5-3.0$ & $70.1-81.0$ & $13.9-18.9$ & $1.1-1.6$ \\
\hline & $24-26$ & $216.0-244.5$ & Expansion cracks 0.5 to $30.0 \mathrm{~cm}$ in length & 2.4-3.5 & $80.9-84.8$ & $23.0-55.0$ & $0.5-1.6$ \\
\hline & 29,30 & $263.5-282.5$ & Core ejected from liner by expansion of gas & $0.6-0.7$ & $90.8-91.7$ & $74.6-109.9$ & $0.5-0.6$ \\
\hline & 34 & $311.0-320.5$ & Expansion cracks; $(3 \mathrm{psi})^{\mathrm{a}}$ & 1.6 & 85.0 & 93.3 & 1.0 \\
\hline & 36 & $330.0-339.5$ & Core ejected from liner; first indication of $\mathrm{C}_{2}$ (ethane) on Carle GC & 0.7 & 84.0 & 168.8 & 0.3 \\
\hline & 37 & $339.5-349.0$ & Core ejected from liner & 1.2 & 82.4 & 175.2 & 0.6 \\
\hline & 38 & $349.0-358.5$ & Core ejected from liner; $(7 \mathrm{psi})^{\mathrm{a}}$ & 0.7 & 84.7 & 194.0 & 0.7 \\
\hline & 39 & $358.5-368.0$ & Core ejected from liner; $(7 \mathrm{psi})^{\mathrm{a}}$; hydrate in core catcher; & & & & \\
\hline & & & gas spl. collected through liner & 0.8 & 80.4 & 194.4 & 1.5 \\
\hline & & & hydrate gas spl. & 0.1 & 90.4 & 501.5 & n.d. \\
\hline & 40 & $368.0-377.5$ & Expansion cracks $(17 \mathrm{psi})^{\mathrm{a}}$ & 0.4 & 92.3 & 389.9 & 0.6 \\
\hline \multirow[t]{3}{*}{ 498A } & 6,8 & $221.5-250.0$ & Core ejected from liner & $0.9-1.1$ & $83.4-83.4$ & $152.4-347.6$ & $3.4-28.0$ \\
\hline & 12 & $278.5-288.0$ & Expansion cracks & 0.1 & 30.6 & 68.2 & 0.6 \\
\hline & 15 & $307.0-316.5$ & Hydrate in vitric sand & 0.2 & 83.0 & 1991 & 4.2 \\
\hline
\end{tabular}

Note: Routine shipboard analyses involve the use of two gas chromatographs (GC units). Gas samples are first analyzed by a Carle GC with a thermal conductivity detector, and from this analysis come the $\mathrm{CO}_{2}$ and $\mathrm{C}_{1}$ data. The Carle unit is relatively insensitive and a Hewlett-Packard GC is employed to quantify $C_{2}$ and heavier hydrocarbons. Analysis via the Hewlett-Packard is a cold-trap technique in which $C_{1}$ is not determined. For complete details, consult Whelan (1979).

${ }^{a}$ Measurement made by puncturing liner with needle fitted with gauge.

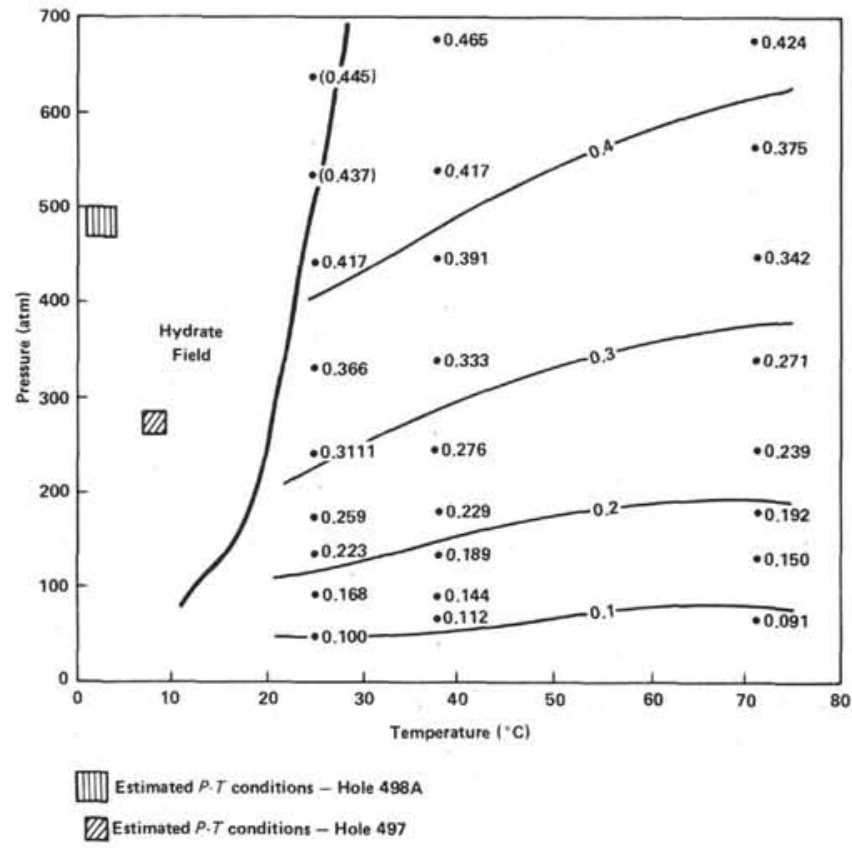

Figure 2. Solubility of pure methane in pure water. (Solid lines are methane concentrations in mole percent. Samples recovered from Holes 497 and $498 \mathrm{~A}$ released 4.08 and 6.10 mole percent methane, respectively, upon coming to ambient $P-T$ conditions. Such concentrations are in excess of those that may be expected from exsolved methane under the $P-T$ conditions of Holes 497 and 498A. [Constructed from the data of Culberson and McKetta, 1951.])

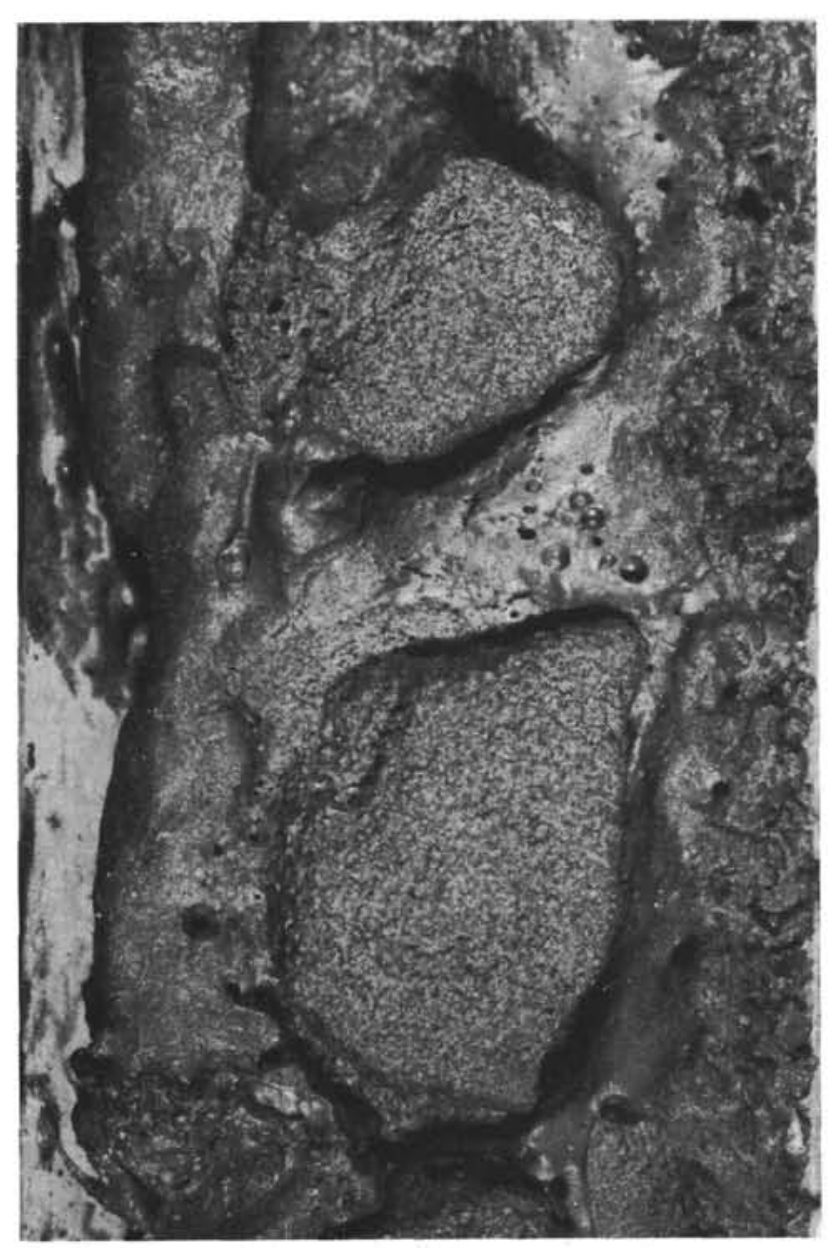

Figure 3. Hydrate-cemented vitric sand recovered at Hole 498A-Sample 498A-15-2, 110-125 cm. (As hydrate melts, sand grains are incorporated into clay-rich slurry. Note small openings that serve as vents for gases released by melting of hydrates. Core liner is 2.54 in. in diameter.) 
mentary rock sequences are anisotropic, and diffusive advance will not define a sphere. Instead, the diffusion front will extend greater distances per unit of time in the direction having more porous and permeable lithology. The random or Brownian movement that causes diffusive movement should permit sands and other high-permeability lithologies to achieve the required concentration of gaseous components more easily than would clay-rich sediments.

There is another relation that may influence the observed association between coarse-grained rocks and gas hydrates. This particular association would be valid only if the gases that formed hydrates resulted from thermally controlled rather than biogenic reactions. The proposed relation may be of academic interest inasmuch as the Deep Sea Drilling Project has involved in excess of 500 sites, and the gases encountered appear to be mainly biogenic in origin. There are, however, regions (e.g., Indonesia) where terrestrially derived sediments and high geothermal gradients occur together, and thus the association warrants at least cursory examination.

The Type I kerogen of Tissot and Welte (1978) is rich in hydrogen and is considered to have good oil- and gasgenerating capability. Type III is relatively low in hydrogen and is thought to be a possible source material for the generation of gas. Type III kerogen is largely composed of higher plant debris and would probably be most abundant in nearshore or transitional depositional environments. Such a setting would probably contain more coarse-grained sediments capable of providing high-porosity lithified rocks. The association between high gas content and coarse-grained sediment has been described from previous DSDP operations. For example, Whelan (1979) reported relatively high levels of methane and ethane in "... coarser grained sediments and discontinuities..." found at Holes 397 and 397A.

The absence of conspicuous BSRs in the seismic records for Leg 67 sites may also be due to the distribution of hydrate-bearing coarse-grained sediment with respect

There are two end-member types of kerogen, each of which has certain chemical and physical characteristics. to muddy sediment. BSRs require that stratigraphic intervals exist in which high-velocity material rests above a reflector and low-velocity material lies below (Paull and Dillon, 1980). Examination of the generalized lithologic column of Sites 494 to 500 (von Huene, Aubouin, et al., 1980) reveals a general paucity of sand-sized material. The lithologic columns described for Leg 66, for example, show considerably more sand than was encountered at Leg 67 sites (Moore et al., 1979). The vitric sands from which hydrates were recovered during Leg 67 were typically 1 to $15 \mathrm{~cm}$ thick and were encased in mudstones several meters thick. Such randomly occurring sand layers would be difficult to discern in most seis- mic records even if the entire pore space had been occupied by hydrates.

\section{ACKNOWLEDGMENTS}

The manuscript was reviewed by Keith Kvenvolden and George Claypool. Their comments were helpful and much appreciated.

\section{REFERENCES}

Bily, C., and Dick, J. W. L., 1974. Naturally occurring gas hydrates in the Mackenzie Delta, N. W. T. Bull. Can. Pet. Geol., 22: 340-352.

Culberson, O. L., and McKetta, J. J., Jr., 1951. Phase equilibria in hydrocarbon-water systems III-the solubility of methane in water at pressures to 10,000 psia. J. Petrol. Technol. (Trans. AIME), 192:223-226.

Hammerschmidt, E. G., 1940. Elimination of hydrate troubles. Oil \& Gas J., 39:61-68.

Heling, D., 1970. Microfabrics of shales and their rearrangement by compaction. Sedimentology, 15:247-260.

Hitchon, B., 1974. Occurrence of natural gas hydrates in sedimentary basins. In Kaplan, I. R. (Ed.), Natural Gases in Marine Sediments. New York (Plenum), pp. 195-225.

Ionescu, L. G., 1978. Entropy of some simple gas-water clathrates. Rev. Roum. Chim., 23:45-53.

Kvenvolden, K. A., and McMenamin, M. A., 1980. Hydrates of natural gas: a review of their geologic occurrence. U.S. Geol. Surv. Circ. 825 .

Makogon, Yu F., Trebin, F. A., Trofimuk, A. A., Tsarev, V. P., and Cherskiy, N. V., 1971. Obnarvzheniye salezhi priorodnogo gaza v trerdom (gazogldratnom) sostoyanii ["Detection of a pool of natural gas in a solid (hydrated gas) state'']. Dokl. Akad. Nauk SSSR, 196:203-206 (in Russian); Dokl. Earth Sci. Sec., 196 (1972): 197-200. (in English)

Milton, D. J., 1976. Methane hydrate in the seafloor-a significant resource? In Meyer, R. F. (Ed.), The Future Supply of Naturemade Petroleum and Gas Technical Reports: New York (Pergamon), pp. 927-943.

Moore, J. C., Watkins, J., et al., 1979. The Middle America Trench off Mexico. Geotimes, 24:20-22.

Parrish, W. R., and Prausnitz, J. M., 1972. Dissociation pressures of gas hydrates formed by gas mixtures. Industrial and Engineering Chemistry. Process Design and Development, 11:26-35.

Paull, Charles K., and Dillon, W. P., 1980. The appearance and distribution of the gas-hydrate reflector off the southeastern United States. U.S. Geol. Surv. Open-File Rep. 80-88.

Tissot, B. P., and Welte, D. H., 1978. Petroleum Formation and Occurrence: Berlin (Springer-Verlag).

Tucholke, B. E., Bryan, G. M., and Ewing, J. I., 1977. Gas-hydrate horizons detected in seismic-profiler data from the western North Atlantic. Am. Assoc. Petrol. Geol. Bull., 61:698-707.

von Huene, R., Aubouin, J., Azema, J., Blackinton, G., Carter, J. A., Coulbourn, W. T., Cowan, D. S., Curiale, J. A., Dengo, C. A., Fass, R. W., Harrison, W., Hesse, R., Hussong, D. M., Ladd, J. W., Muzylöv, N., Shiki, T., Thompson, P. R., and Westberg, J., 1980. Leg 67: The Deep Sea Drilling Project Mid-America Trench transect off Guatemala. Geol. Soc. Am. Bull., Pt. 1, 91:421-432.

Whelan, Jean K., 1979. $C_{1}$ to $C_{7}$ hydrocarbons from IPOD Holes 397 and 397A. In von Rad, U., Ryan, W. B. F., et al., Init. Repts. DSDP, 47, Pt. 1: Washington (U.S. Govt. Printing Office), 531-539.

Yefremova, A. G., and Zhizhchenko, B. P., 1974. Obnaruzheniye kristallgidradov gazov v osadkakh sovremennykh akvatoriy ["Occurrence of crystal hydrates of gases in the sediments of modern marine basins"']. Dokl. Akad. Nauk SSSR, 214:1179-1181 (in Russian); Dokl. Earth Sci. Sect., 214 (1975):219-220. (in English) 